Article

\title{
An Assessment of Police Officers' Perception of Hotspots: What Can Be Done to Improve Officer's Situational Awareness?
}

\author{
Venezija Ilijazi ${ }^{1}\left(\mathbb{D}\right.$, Nenad Milic $^{2}$, Dragan Milidragovic ${ }^{1}$ and Brankica Popovic ${ }^{3, *}$ (I) \\ 1 Ministry of Interior, Republic of Serbia, 11000 Belgrade, Serbia; venezija.ilijazi@mup.gov.rs (V.I.); \\ dragan.milidragovic@mup.gov.rs (D.M.) \\ 2 Department of Criminalistics, University of Criminal Investigation and Police Studies, 11080 Belgrade, \\ Serbia; nenad.milic@kpu.edu.rs \\ 3 Department of Informatics and Computer Science, University of Criminal Investigation and Police Studies, \\ 11080 Belgrade, Serbia \\ * Correspondence: brankica.popovic@kpu.edu.rs
}

Received: 17 April 2019; Accepted: 28 May 2019; Published: 1 June 2019

\begin{abstract}
The idea behind patrol activity is that police officers should be the persons best acquainted with the events and people in their patrol area. This implies that they should have access to relevant data and information (e.g., where and how to pay attention, when and how crimes are committed) in order to effectively perform their police duties. To what extent their perceptions of the places prone to crime (hotspots) are accurate and what the implications are for police efficiency if they are incorrect is an important question for law enforcement officials. This paper presents the results of a study on police practice in Serbia. The study was conducted on a sample of 54 police officers and aimed to determine the accuracy of the perception of residential burglary hotspots and to evaluate the ways police officers are informed about crimes. The results of the study have shown that the situational awareness of police officers is not at a desired level, with ineffective dissemination of relevant data and information as one of the possible reasons.
\end{abstract}

Keywords: police; crime analysis; GIS; residential burglaries; spatial perception; crime mapping

\section{Introduction}

Police activity is highly dependent on timely and thorough collection of relevant data [1,2] They are vital for crime prevention, as well as for effective crime investigation [3-5]. Accordingly, data and information collection, processing, analysis, and dissemination become an integral part of policing [2]. Everyone, from law enforcement managers to police officers and police support staff, relies on accurate and timely data and information, necessary for them to perform their duties [6]. According to Brown, $92 \%$ of an officer's time is spent acquiring, coalescing or distributing them [7].

In reactive (traditional) policing, collected data and information were primarily related to the offenders and the crimes they commit [8]. The modern policing era requires a shift towards proactive police work and refocusing attention from incidents to problems that are to be discovered and solved in partnership with the community [9]. Intelligence-led policing (ILP), problem-oriented policing, predictive policing etc. places a much bigger demand for information on the police [10]. This information is collected from an increasing number of sources and does not relate only to crime and its perpetrators, but also to various aspects of the environment in which criminal activity emerges and where the police organization performs its function [2]. It enables more efficient identification of a problem, ascertaining the cause and devising effective actions towards its elimination [11]. 
Greater information availability also raises new demands for police officers and police organizations. Police officers are expected to use it and think analytically, to make hypotheses related to the cause of the problem and the perpetrators in their patrol area and to verify some of it [12-14]. At the same time, a police organization is expected to improve its analytical capacity, to implement the latest achievements in the area of the information and communication technology, and produce timely, relevant, accurate, complete, and verified information to be used for everyday policing [15]. In an effort to get high-quality information, one fact is usually overlooked-any investment in the development of the police organization's analytical capacity will fail if information does not reach, or is not used by those who are intended to use it: Front line police officers [2]. Therefore, it is necessary to carry out research that will show whether information dissemination channels are adequate or whether and to what extent the much-needed information is used in the daily work of police officers.

This paper presents the results of the study on current police practice in the Republic of Serbia aimed at finding out how police officers are informed about the crime incidents occurrence and how well they perceive the spatial distribution of crimes (hotspots locations).

The rest of the paper is organized as follows: The second section refers to the research on the accuracy of police officers' perceptions of hotspots areas; an overview of relevant literature is given, along with an explanation of the approach used in this research. In the third section, methodology is described, followed by the results presentation in Section 4. Discussion of results is given in the fifth section. The paper ends with the conclusion.

\section{Research on the Accuracy of Police Officers' Perceptions of Vulnerable Areas}

One of the common stereotypes found in the police practice is that police officers are persons best acquainted with the events and people in their patrol areas [16]. The essence of patrol activity is the assignment of patrol officers to specific geographical areas (beats) on a regular basis. Police officers visit their patrol area, observe the activities of those staying in that area, communicate with people who live and work there, and gain knowledge about problematic places, persons, and behaviors. Based on the knowledge accumulated over time, it is expected that they know when and how crimes are committed, who is a possible offender, where to look for necessary information, etc.

To a large extent, police officers' field activities are guided by the knowledge they possess, so the lack of or inaccurate knowledge can reduce their efficiency. If police officers consider themselves well acquainted with the relevant issues, it is unlikely that they will recognize the necessity to verify or update their knowledge with information from other sources. Bearing that in mind, to what extent police officers have knowledge of the location of the crime, or what is needed to be done in order to make these locations less attractive for criminal activity, may be a significant indicator of (in)adequacy of data and information collection and/or the dissemination process that exists within a police organization [16]. One way to investigate this is to analyze police officers' perception of hotspot areas.

When it comes to a research on how citizens perceive crime in the area where they live, there is a great body of literature related to exploration of citizens' fear of crimes and their perception of dangerous places [17-20]. However, evaluations of the accuracy of frontline police officers' perception related to hotspots are rare in the scientific literature. Investigating the accuracy of Philadelphia (USA) police recruiters' perception of where crime concentrates, Rengert and Pelfrey concluded that their attitude related to the location of dangerous and safe areas was not accurate since the primary factor in determining a physical environment as a (not) safe one was not the actual knowledge of the area but their perception of the physical environment's ethnic structure [21]. Ratcliffe and McCullagh studied the perceptions of police officers in Nottinghamshire (England) on where car thefts, burglaries in residential, and burglaries in commercial buildings were frequently carried out. The authors concluded that the accuracy of police officers' perception was highest with apartment burglaries (about $60 \%$ of the correct 'guesses'), and lower with the other two groups of theft [16]. In a survey conducted with 
police officers in Kentucky, USA, Paulsen asked respondents to mark on a map five territorial units they believed had the highest crime rate. He concluded that police officers have fairly inaccurate perceptions of geospatial patterns of crime manifestation [22]. Research conducted by Lopez and Lukinbeal showed that police perception was heavily influenced by reported crimes [23].

The research of police officers' perceptions of crime hot spot locations is usually done in a way that spatial distribution of crimes is analyzed in order to detect hotspots. Afterward, the identified hotspots are compared with the locations marked by the police officers-respondents (these locations will be referred to as 'police officer perceptions') as the locations where they believe hot spots exist. Based on how their perceptions are aligned with the location of the crime incidents, the conclusion is made whether the risk in these areas can be categorized as known, unknown or partially known. However, in these and similar studies, one equally important aspect remains neglected. The attention of the researchers was not focused on the areas where there are no criminal activities (according to official police records), but police officers falsely believed that criminal activity is concentrated there. Identifying these areas is just as important as identifying areas where crimes are actually happening. If police officers know locations where crime is concentrated, it is highly likely that they will be in the right place at the right time ready to prevent crime. However, if they believe they are 'in the right place', but this location is not crime hotspot, citizens in the area where crimes actually happen are deprived of their protection. In either case, the desired results of police engagement are reduced or missing, as police officers are spending their time in the area where there is no need for their (focused) engagement.

Keeping in mind the arguments mentioned above, the intention of this research was not only to determine the extent to which officers' perceptions are aligned with the official crime data (crimes reported to the police- 'true' hotspots) but also to identify the existence of 'false' hotspots-areas that police officers incorrectly perceive as high-risk areas.

In order to achieve that, in this research, a different approach for hotspot detection was used. Instead of applying well-known spatial statistics methods like kernel density or Getis Ord Gi* [16,24], the research area was partitioned into smaller aerial units-so-called atoms (the partitioning process will be further elaborated on in the Methodology section), where each atom serves as a possible hot spot. Based on the number of crimes committed and the number of police perceptions inside each atom, a conclusion was made as to what the crime risk of each of these atoms is and to what extent this risk is known to the police officers.

If many crimes were committed in the area of an atom, but this space was not marked as 'hot' by the respondents, this may indicate that police officers do not possess sufficient knowledge about its crime risk. Conversely, areas marked by the respondents as 'hot' but not containing crime locations (this area either does not have crimes at all or has an insufficient number of crimes to make up a hotspot) indicate that police officers have wrong perception of crime there. This may have important implications on policing and requires further consideration.

\section{Methodology}

\subsection{Data Source}

Research on the accuracy of police perceptions of hotspots was based on a three-year (2012-2014) residential burglary dataset of the Novi Beograd area. During the research period, a total of 536 residential burglaries were committed. Each crime location was manually geocoded, and ArcGIS software was used for the analysis and visualization of crime distribution.

\subsection{Study Area}

The study of police officer perceptions was carried out in 2015 at the Police Station of Novi Beograd. The Municipality of Novi Beograd is one of the 17 municipalities of the City of Belgrade (which is the capital of the Republic of Serbia), and according to the official data, it has 214,506 inhabitants 
(with permanent residence), while the estimates of the Republic of Serbia Ministry of Interior state that 300,000 inhabitants live in the territory of this municipality. Novi Beograd is a highly urbanized municipality covering 4096 hectares of land and having over 200 skyscrapers, 600 large buildings, and 91,000 apartments.

\section{Study Area Partitioning-Creating of Atoms}

A hot spot is defined as crime concentration at very small micro unit of analysis [13,25]. According to Braga and Weisburd, in traditional policing, police routinely defined their units of operation in terms of large areas, such as police precincts and beats. In hot spot policing, hotspot refers to a 'micro unit of analysis' or 'small units of geography' [13]. In one of the first definitions of hotspot, it is described as an area 'that can be seen completely and simultaneously, at least on its surface, by one's naked eye' [26], or an area whose boundaries are 'easily visible from an epicentre' [27]. Places in this context are very small micro units of analysis, such as buildings or addresses; block faces or street segment; and clusters of addresses, block faces, or street segments [13]. However, in practice, it is not easy to determine hotspots' boundaries. It is often unclear where a hotspot begins and where it ends [28]. When it comes to the hotspot identification, Guidi et al. (as cited by Farrell et al.) give one of the most specific guidelines in terms of how to determine the boundaries of a hotspot [29]. They point out that optimal-size hotspots have a 100 to $300 \mathrm{~m}$ radius, which depends on the local characteristics of the area under analysis. In the case of a densely populated area, the size of a crime hotspot can be closer to the lower $100 \mathrm{~m}$ limit.

The process of partitioning the territory-the creation of atoms-began by excluding the parts of the study area where residential burglaries cannot be committed, i.e., space where there are no residential units. Therefore, recreational areas (parks), areas with commercial buildings (e.g., shopping centers), administrative facilities (local self-government buildings, state administration, schools, etc.), parking lots, rural areas, etc. were excluded. Afterwards, the remaining area was divided into 76 micro units-atoms. The size of the atoms was in accordance with the recommendations suggested in the hotspot literature. As a rule, they covered a single city block defined by surrounding roads and had characteristics of what Weisburd denotes as behavior settings. This is a type of setting where, according to Weisburd, people recognize each other and their habits of behavior, evolve into complementary roles, and develop shared norms [30]. In most cases, atoms were polygons a single side of which did not exceed $500 \mathrm{~m}$. The exception was the atoms in the rural part of the research area-this area was not densely populated and contains scattered single-family houses, compared to the density of residential buildings in the urban part of the municipality of Novi Beograd.

The largest atom had a surface area of $1.27 \mathrm{~km}^{2}$ (it is located in the western, rural part of the area under analysis), while the smallest atom had a surface area of $0.021 \mathrm{~km}^{2}$. The average surface area of all atoms was $0.146 \mathrm{~km}^{2}(\mathrm{SD}=0.154)$.

\subsection{Participants}

The sample comprised 54 police officers and included all police officers who were on duty when data collection was carried out. The respondents were asked to mark on the A3 format orthophoto map of Novi Beograd, printed in color, the locations where according to their knowledge, residential burglary crimes were concentrated (hotspots). Prior to starting the marking process, the respondents were asked to locate two landmarks (e.g., municipal building, shopping mall) in order to familiarize themselves and read the map correctly. The respondents were not limited in terms of the number of locations they were supposed to mark - they could mark as many as they deemed necessary. They were not limited by their (patrol) area either, i.e., they could mark locations inside and/or outside their patrol areas. This is due to the fact that their knowledge is not limited to the area they regularly patrol, because they may be requested to patrol other areas as well (e.g., shortage of manpower). Further, during briefing, officers are exposed to information about the problems on the whole police station area-not only those pertaining to their patrol area. 


\subsection{Index Measure (IM)}

The accuracy of the perception of police officers was analyzed by calculating the index measure (IM) for each atom. IM represents the ratio of the number of locations marked by police officers, which they believe are places where crime is often committed (p), and the number of real crime locations (c). Thus, for each atom, IM was calculated as:

$$
\mathrm{IM}=\mathrm{p} / \mathrm{c} .
$$

\section{Results}

A total of 428 locations were marked by the 54 respondents who took part in the survey and mapped using the ArcGIS software (Figure 1).

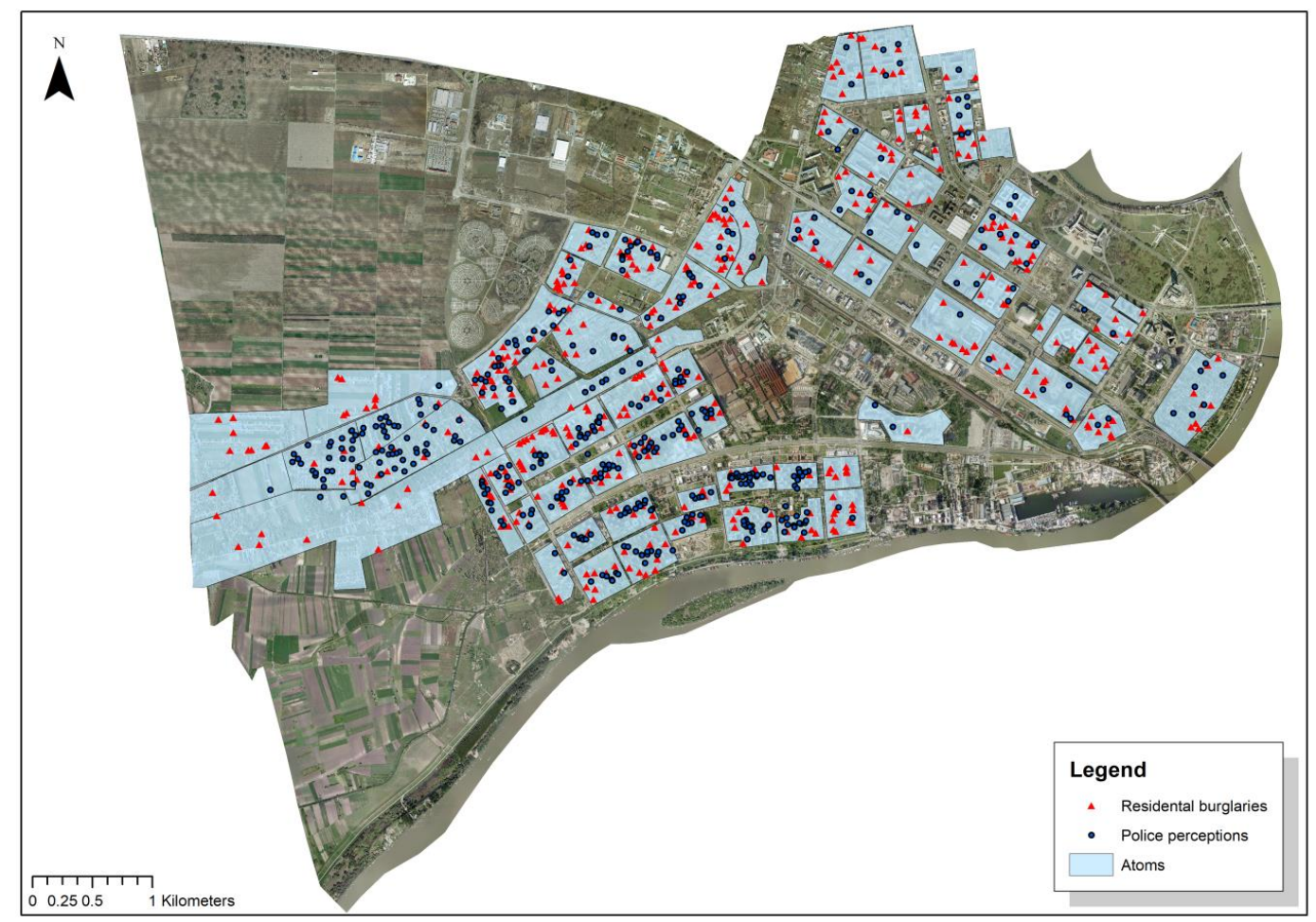

Figure 1. Spatial distribution of atoms with locations of crimes and marked locations ('perception') of police officers.

Three respondents, out of 54, marked only one location, while the maximum number of locations marked by a single respondent was 32. The largest number of respondents marked 1 to 5 locations (23 respondents), 14 respondents marked 6 to 8 locations, while 10 respondents marked 9 to 15 locations. Four respondents marked 16 to 20 locations, while two respondents marked over 20 locations.

The accuracy of the locations marked by the respondents was determined by comparing them with the locations where residential burglaries were actually committed, in the period of three years prior to the study (2012-2014).

The accuracy of police officer perceptions was considered by analyzing the values of the IM index calculated by the formula (1). Namely, if in some atoms, there are significantly more crime locations, and none or few locations (perceptions) marked by the police officers as vulnerable or 'hot' $(\mathrm{IM}<1)$, this may indicate that police officers do not have a good (accurate) perception of the vulnerability of this area. A similar conclusion can be made for the areas considered vulnerable by many police officers, thus having many marked locations, but with a few actually committed crimes (IM > 1). In the former case, the police officers consider a certain environment as safe(r), although this is not the case, while in 
the latter case, they consider a particular area to be more vulnerable than it actually is. In this way, the value of the IM ratio may indicate that the subjective police officer's perception of crime risk is not in accordance with the actual crime risk in that area.

The spatial distribution of the IM index for different atoms in the research area can be seen in Figure 2, while more detailed data can be found in table shown in Figure 3.

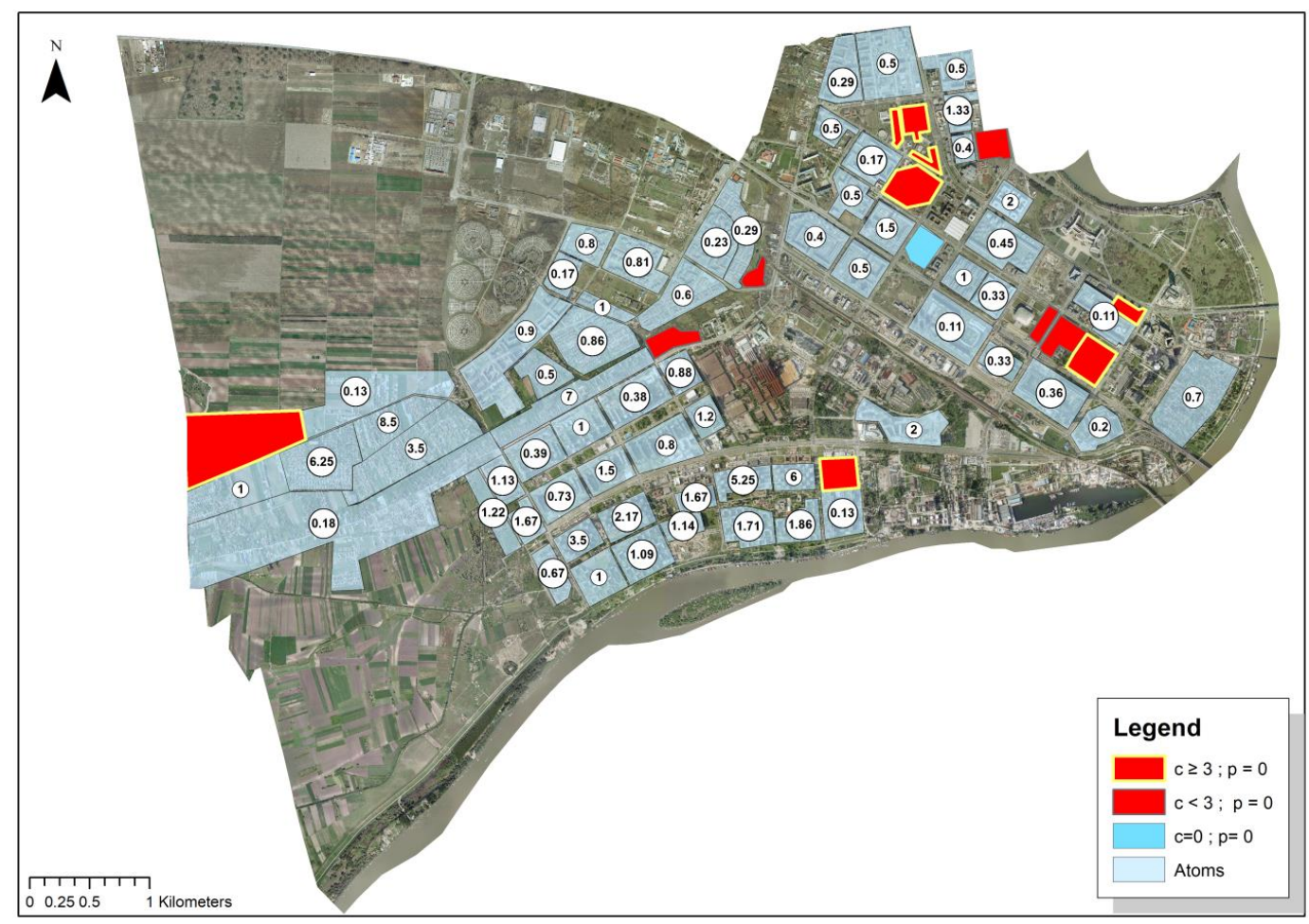

Figure 2. Different index measure (IM) values in the research area.

\begin{tabular}{|c|c|c|c|c|c|c|c|c|c|c|c|c|c|}
\hline \multirow[t]{2}{*}{ IM index } & \multirow[t]{2}{*}{$\begin{array}{l}\text { No of } \\
\text { atoms }\end{array}$} & \multicolumn{2}{|c|}{$\begin{array}{c}\text { Atom surface } \\
\text { area }\end{array}$} & \multicolumn{2}{|c|}{$\begin{array}{c}\text { Total number } \\
\text { of residential } \\
\text { burglaries } \\
\text { inside atoms } \\
2012-2014 \\
\end{array}$} & \multicolumn{2}{|c|}{$\begin{array}{c}\text { Residential } \\
\text { burglaries } \\
{[2014]}\end{array}$} & \multicolumn{2}{|c|}{$\begin{array}{c}\text { Residential } \\
\text { burglaries } \\
\text { [2013] }\end{array}$} & \multicolumn{2}{|c|}{$\begin{array}{c}\text { Residential } \\
\text { burglaries } \\
\text { [2012] }\end{array}$} & \multirow[t]{2}{*}{$\begin{array}{c}\text { No. of } \\
\text { perceptions }\end{array}$} & \multirow[t]{2}{*}{$\begin{array}{l}\text { No. of } \\
\text { police } \\
\text { officers }\end{array}$} \\
\hline & & $\begin{array}{c}\mathrm{P} \\
\left(\mathrm{km}^{2}\right)\end{array}$ & $\%$ & No. & $\%$ & No. & $\%$ & No. & $\%$ & No. & $\%$ & & \\
\hline$c \geq 3 ; p=0$ & 8 & 0.86 & 7.61 & 41 & 7.65 & 12 & 9.38 & 10 & 4.85 & 19 & 9.41 & 1 & 1 \\
\hline$c<3 ; p=0$ & 5 & 0.26 & 2.30 & 8 & 1.49 & 3 & 2.34 & 2 & 0.97 & 3 & 1.49 & 1 & 1 \\
\hline $\mathrm{IM} \leq 0.25$ & 9 & 2.59 & 22.93 & 102 & 19.03 & 23 & 17.97 & 40 & 19.42 & 39 & 19.31 & 17 & 11 \\
\hline $0.25<\mathrm{IM} \leq 0.5$ & 16 & 2.13 & 18.86 & 131 & 24.44 & 39 & 30.47 & 48 & 23.30 & 44 & 21.78 & 53 & 19 \\
\hline $0.5<\mathrm{IM}<1$ & 10 & 1.87 & 16.56 & 126 & 23.51 & 26 & 20.31 & 49 & 23.79 & 51 & 25.25 & 100 & 32 \\
\hline $\mathrm{IM}=1$ & 5 & 0.67 & 5.93 & 24 & 4.48 & 3 & 2.34 & 12 & 5.83 & 9 & 4.45 & 24 & 24 \\
\hline $1<\mathrm{IM}<2$ & 12 & 1.15 & 10.18 & 73 & 13.62 & 15 & 11.72 & 38 & 18.45 & 20 & 9.9 & 100 & 29 \\
\hline $2 \leq \mathrm{IM} \leq 3$ & 3 & 0.35 & 3.10 & 8 & 1.49 & 3 & 2.34 & 3 & 1.46 & 2 & 0.99 & 17 & 13 \\
\hline $\mathrm{IM}>3$ & 7 & 1.35 & 11.95 & 23 & 4.29 & 4 & 3.13 & 4 & 1.94 & 15 & 7.43 & 117 & 33 \\
\hline TOTAL & 75 & 11.23 & 99.4 & 536 & 100 & 128 & 100 & 206 & 100 & 202 & 100 & 428 & 54 \\
\hline
\end{tabular}

Figure 3. Detailed presentation of research results.

Of the total of 76 atoms, in one of them, there was no crime of residential burglary $(c=0)$, nor was it marked by any participant $(\mathrm{p}=0)$. It is marked in blue in Figure 2 and is not shown in the table view (a total of 75 atoms are shown).

By analyzing the results in Figure 3, it can be noticed that more than 3 crimes (c $\geq 3$ ) per atom (a total of 41 crimes) were committed in 8 atoms and 1 to 3 crimes (c $<3)$ per atom were committed in another 5 atoms (a total of 8 crimes). In these atoms (9.91\% of the research area), none of the 
respondents marked at least one location $(\mathrm{p}=0)$. Based on the fact that in the year preceding the study (2014), 15 crimes (11.72\% of the total number of crimes committed during that year) were committed in that area, it may be reasonably assumed that this area is out of the attention of surveyed police officers. Inaccurate perceptions also exist inside 9 atoms (IM $\leq 0.25)$, where 102 crimes were committed (almost $20 \%$ of the total number of crimes), with only 11 police officers (out of 54 ) marking only 17 critical locations within these polygons. This further means that in the area that covers 22 atoms $(8+5$ $+9)$, whose surface area is almost $1 / 3$ of the research area $(32.84 \%)$ and where, in the period under research, just over $1 / 4$ of the total number of crimes (151 crimes) were committed, only 11 police officers (out of 54) marked 17 critical locations (out of a total of 428 locations) they consider endangered by residential burglaries.

Fairly better accuracy exists in 16 atoms $(0.25<\mathrm{IM} \leq 0.5)$ that make up $18.64 \%$ of the total research area, in which 131 residential burglaries were committed and in which less than half of the respondents, 19 of them, marked 53 locations ( $12 \%$ of the total number of locations marked by the respondents).

The greatest number of respondents placed their perceptions inside $27(10+5+12)$ atoms $(0.5<\mathrm{IM}<2)$ in which almost $42 \%$ ( 223 crimes) of the residential burglaries were committed. More than half of the total number of perceptions was placed in the area of $3.69 \mathrm{~km}^{2}(32.67 \%$ of the total area of the atoms). Keeping in mind the number of respondents who marked at least one location in the given area and the ratio between the marked locations and the committed crimes (IM), we may conclude that it is an environment in which the residential burglary risk is well known to police officers.

In a smaller area ( 3 atoms with a surface area of $0.35 \mathrm{~km}^{2}$ ), the number of marked locations is 2-3 times higher than the number of crimes committed $(2<\mathrm{IM} \leq 3)$, which may indicate that the subjective assessment of that area by the respondents is not in line with the existing crime risk. This is particularly evident in 7 atoms where police officers marked locations in a number significantly higher than the actual number of crimes committed in this (micro) environment (IM > 3). Namely, in an area that covers $1.35 \mathrm{~km}^{2}$ (11.95\% of the total research area), 33 police officers (61\% of the total number of respondents) marked 117 locations ( $48 \%$ out of a total of 243 locations marked by these respondents, or $27 \%$ of the total number of locations marked by all respondents) (Figure 4 ). At the same time, 23 crimes were actually committed there in the three-year period, with only 4 crimes committed in the year preceding the research-2014 (Figure 3).

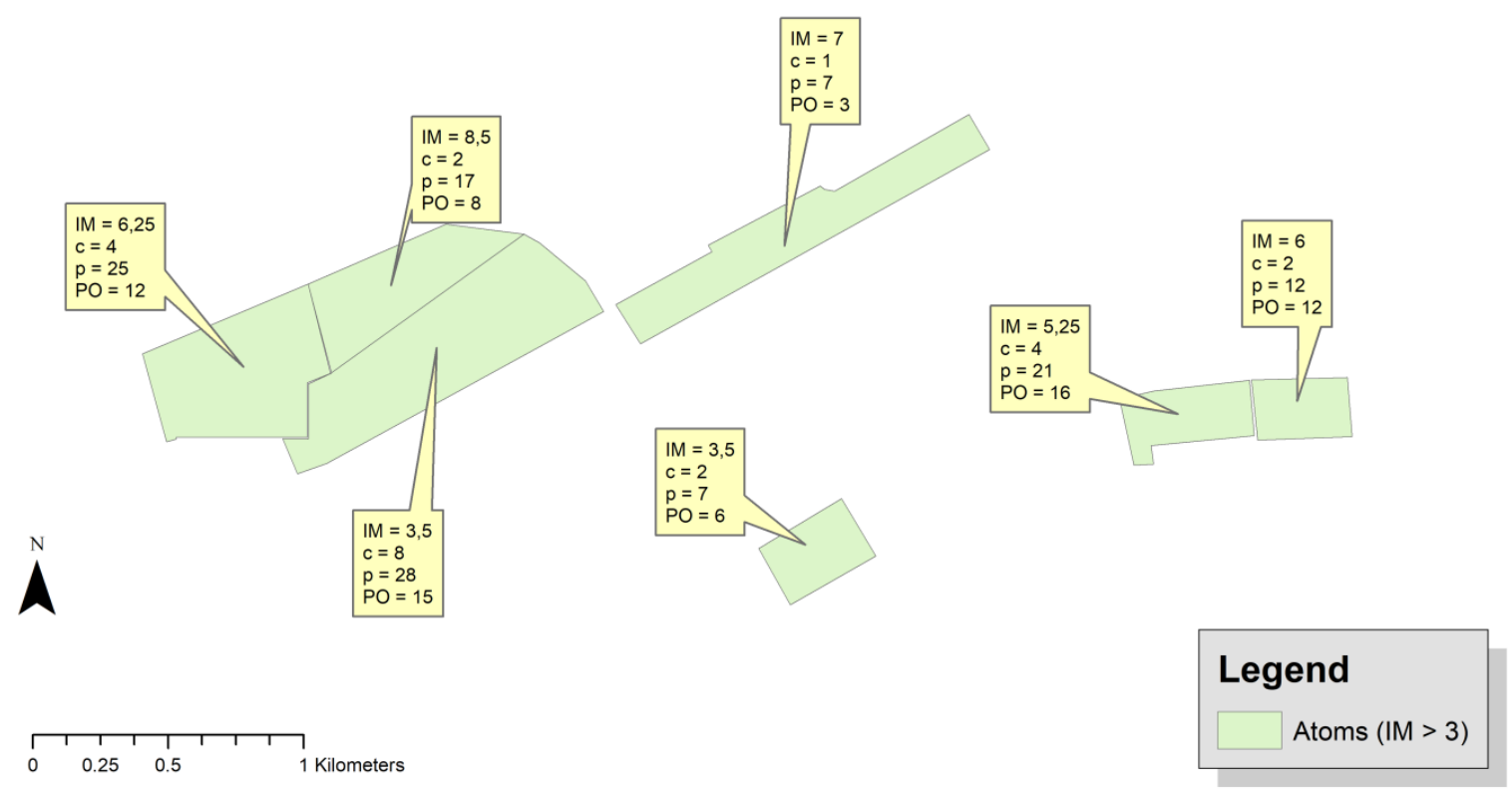

Figure 4. Atoms with $\mathrm{IM}>3$ ( $\mathrm{c}$ - the number of crimes inside the atom, $\mathrm{p}$ - the number of police perceptions inside the atom, $\mathrm{PO}$ - the number of police officers who placed their perceptions inside the atom). 
Finally, if one takes into account that each police officer could place more perceptions within an atom, it is interesting to compare the number of crimes and the number of police officers who marked at least one location within the atom. For example, six perceptions placed inside an atom can come from one or six police officers-however, it is not the same whether the risk was accurately perceived by one or all six police officers. Figure 5 shows, for each atom, the number of crimes and the number of police officers who placed their perception inside (at least one perception). Atoms with many crimes committed inside them but marked as vulnerable by a small number of police officers indicate 'underestimated risk', and atoms which are considered vulnerable ('hot') by many police officers but with a small number of crimes indicate 'exaggerated risk'. In both cases, there is inaccurate risk perception.

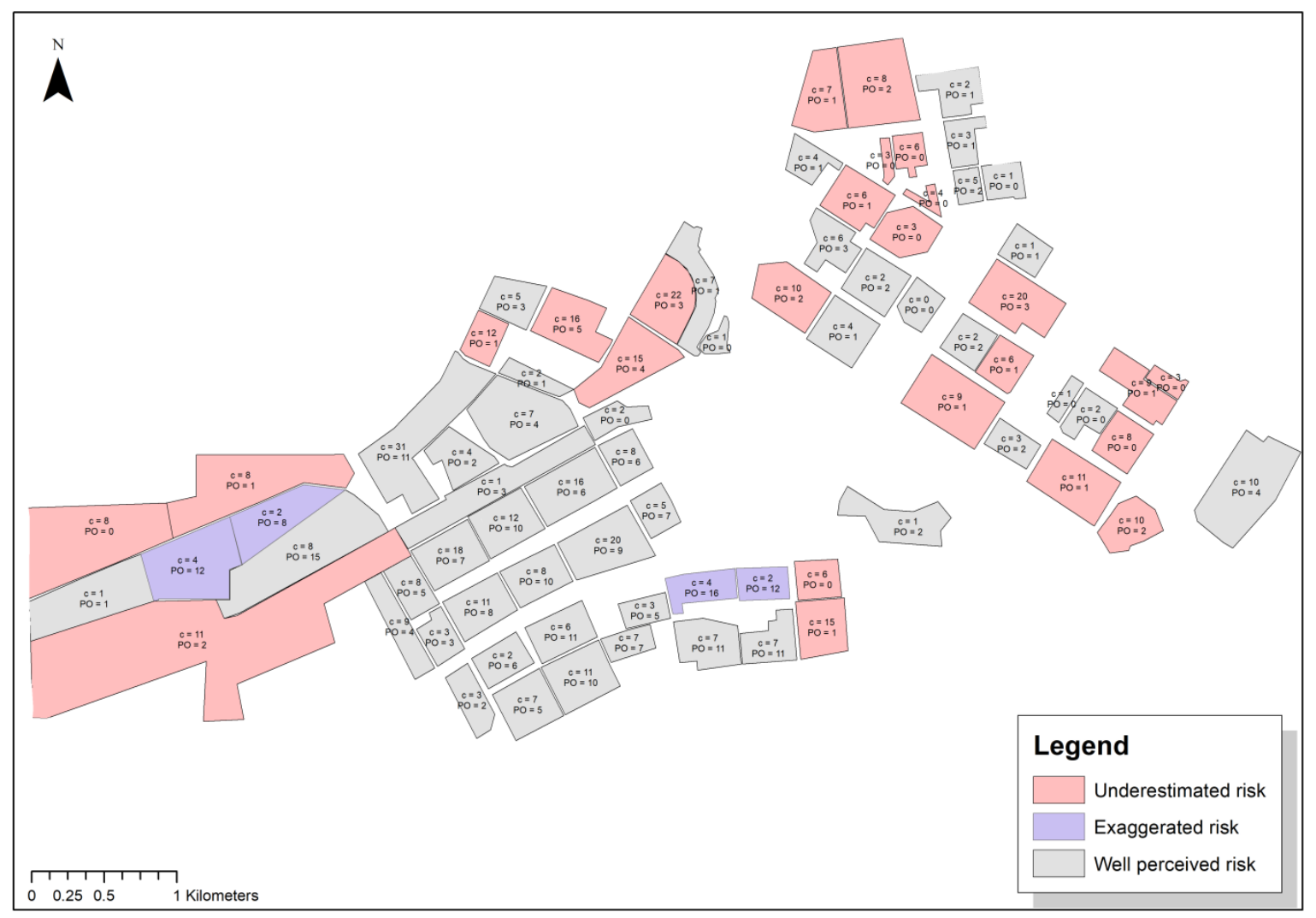

Figure 5. The number of crimes (c) in atoms and the number of police officers (PO) who marked at least one location within the atom.

There are 4 atoms with exaggerated risk and 25 atoms with underestimated risk. Well perceived risk is present in 47 atoms. The number of atoms where risk is well perceived is greater than those where exaggerated or underestimated risk is perceived ( $47 \mathrm{vs.} \mathrm{29).} \mathrm{When} \mathrm{surface} \mathrm{area} \mathrm{is} \mathrm{compared,}$ approximately the same area is entailed by atoms where risk is well perceived and those with exaggerated or underestimated risk $\left(5.80 \mathrm{~km}^{2}\right.$ vs. $\left.5.69 \mathrm{~km}^{2}\right)$, as shown in Table 1.

Table 1. Number of atoms with associated level of risk.

\begin{tabular}{ccc}
\hline & Number of Atoms & Total Surface Area of Atoms \\
\hline Underestimated risk & 25 & 4.86 \\
Exaggerated risk & 4 & 0.63 \\
Well perceived risk & 47 & 5.80 \\
TOTAL & 76 & 11.29 \\
\hline
\end{tabular}




\section{Discussion}

Many crimes committed in atoms that are not marked by the officers as 'hot' may indicate that they do not possess sufficient knowledge about the crime risk of these areas. At the same time, areas police officers believe are crime-prone, but with no pronounced criminal activity (this area either does not have crimes at all or has an insufficient number of crimes to constitute a hotspot), may also indicate inaccuracy of police perceptions. However, in the latter case, caution should be exercised. In fact, it is possible that due to perceived high risk, officers are spending more time in that area and due to their presence, criminal activity is deterred (prevented). This could be an explanation for absence or low level of criminal activity in that area. In the case their perception was true, their presence in that area is justifiable and the outcome is desirable-less crime. Data collected from a longer time span than the one used in this research may show that those areas used to be problematic in the past. Due to their previous crime history, officers still perceived them as risky, but because of their ongoing engagement, they now have less crime. At the same time, it is possible that crime is happening in a particular area, but it is not reported to police (dark figure of crime). Frontline officers know that, due to their familiarity with their patrol areas, but crime analysts and police supervisors do not. As a consequence, they may interpret officers' perceptions as inaccurate. Finally, in the case it is proved that there is no 'hidden' criminal activity and the officer's perceptions are inaccurate, then (excessive) police presence in 'safe' areas leaves other areas, where crimes are actually committed, without protection.

Based on the number of atoms that are out of the attention of police officers and those areas deemed vulnerable by them but with no (pronounced) residential burglary activity, one can conclude that police officers' knowledge of their patrol area is not at a level that can ensure efficient policing. One of the possible causes of such a situation is the inadequate informing of police officers. Research on police practice in Serbia shows that the most common ways of informing police officers include radio communication they are listening to while on duty, briefing preceding their shift (roll call), information obtained by reviewing daily crime bulletins, personal experience and observations, and exchange of information with colleagues [24].

When police officers come to take their shift, they rarely know what happened in their (patrol) area while they were absent. In this regard, the roll call briefing is a valuable source of information. In Serbia, like in many other countries, roll calls are of limited duration (usually up to 20 minutes), and informing about crime is not the only content presented. They are usually limited to recent events (only to those that are more serious) that happened during the last 24-48 $\mathrm{h}$ [31]. For someone who has been away for 2-3 days or more from their (patrol) area, this may be insufficient. During roll calls, information is usually shared orally. According to research conducted by Scholtens et al. (as cited by Lukosch et al.), information presented through a roll call is only partly remembered later by police officers (60\% of the information cannot be recalled by police officers) [32]. A similar conclusion could also be applied to information obtained by reading daily crime bulletins, which usually comprise data about the events that happened over the past $24 \mathrm{~h}$.

When police officers are on duty, one of the main information sources is their personal experience and observation. Police officers visit their patrol area, observe the activities of those who stay in that area, communicate with people who live and work there, and gain knowledge about problematic places, persons, and behaviors. Instead of being assigned to a single patrol area, due to budget cuts and shortage of manpower, police officers are frequently rotated among different patrol areas. As a result, officers' awareness of the everyday events is decreased. A study of police practice in Serbia showed that moving officers from one area to another is quite frequent [24]; therefore, it is reasonable to ask to which extent police officers are able to directly observe ('see' and 'hear') relevant events on their patrol area.

While on patrol, police officers are listening to radio communication and in this way, they are informing themselves about the events they do not directly take part in. The fact that not all calls are forwarded by the dispatch officer via the radio, and that by the very arrival at the scene, a police patrol is able to determine that the call initiating their action does not necessarily contain elements of 
crime (e.g., a crime is reported and turns out to be a misdemeanor or false reporting), points out the deficiencies of this information source.

Likewise, when talking to their colleagues, police officers exchange information and get new insights. However, there may be situations where police officers may be reluctant to share their knowledge, usually because fellow colleagues may be considered as competition on the way towards promotion. Competition may exist not only among single police officers, but between officers assigned to different patrol areas, to different shifts, units (e.g., uniformed officers vs. detectives), etc. That is a reason why the police organization needs to promote a culture of openness, collaboration, and sharing information among police officers [33].

Police officers do not have the ability to memorize all crime incidents and compare ongoing crime activity with past crimes in order to identify crime patterns, and make reliable conclusions about offenders, risky places, etc. In these cases, a crime analysis unit comes to the fore. Quality analytical products (e.g., crime bulletins) allow police officers to better identify and assess (anticipate) a threat posed by certain criminal activity and develop an effective strategy of action before they escalate. In this way, they could be in the right place at the right time to prevent a crime. No matter how good they are, analytical products lose their value if not acted upon or not reaching frontline police officers [2]. For example, O'Shea and Nicholls state that analytical products are directed exclusively to managers or detectives [34]. According to Taylor et al., few patrol officers use crime analysis or have contact with crime analysis personnel [35]. Investigating the practice of problem-oriented work in San Diego, USA, Cordner and Biebel found that out of all sources of information available to a police officer during problem analyzing (the authors identified 16 sources), information obtained from the crime analysis unit is least frequently used (about $6 \%$ of the respondents), while personal observations were the most often used source of information (58\%) [12]. Unfortunately, confirmation of these conclusions is also found in the research of Serbian police practice, where it has been shown that analytical support to frontline police officers is almost nonexistent, and that almost $80 \%$ of the respondents carry out their duties with no support from analysts, relying mainly on their (personal) observation, memory, and experience [24].

Having in mind the dynamic environment (people, places, procedures, etc.) in which police activities are performed, the availability of timely and accurate information is of crucial importance. In order to improve the dissemination of relevant information to police officers, the police organization is turning to mobile technologies [36] Bearing in mind the limits of 'traditional' ways of informing police officers (personal observation, two-way radios, exchange of information with co-workers, reading crime bulletins, etc.), a mobile application that would allow police officers $24 / 7$ access to relevant information is a tool that may improve the situational awareness of police officers, especially during the time police officers are away from their patrol areas. It can make them less dependent on what is heard and remembered during roll calls, what is read in crime bulletins, etc. [32]. Empowered with more information, police officers may be in the right place at the right time, ready to act proactively and to prevent crime.

The partitioning approach used in this paper (atoms) enables easy identification of micro areas where risk is out of the attention of police officers. As soon as an atom 'pops up' because of an increased number of crimes, the attention of police supervisors is easily attracted. The micro size of atoms makes them suitable for analysis. In larger areas, multiple problems may exist, some of which may be quite complex, which can make police efforts to determine its causes more difficult [13]. In this regard, as it is noted by Sherman, larger areas are not only too big to treat, they are also too large in size and too small in number to evaluate the effects of treatments [37]. Heterogeneity of crime within communities [38] reinforces the importance of focusing crime prevention resources at micro units.

A police station/district area that is already partitioned into atoms (possible hot spots) can be used as a sort of 'early warning system'. Police supervisors could use them to monitor crime distribution by simply counting crimes inside atoms, and as soon as they reach a certain threshold, they can immediately focus attention on a particular atom. Supervisors should periodically map police 
officers' perceptions and examine them by making comparisons with crime distribution across atoms. An alternative is to use some of the spatial statistics methods (e.g., Getis Ord $\mathrm{Gi}^{*}$ ), which may offer grater statistical robustness but require some technical skills and are challenged with the subjectivity of their parameters' selection [39-41].

The partitioning process can be challenging and must involve great familiarity with the studied area. Once partitioned, atoms could be later modified in order to better reflect the dynamic of a specific micro area (behavior setting).

\section{Conclusions}

Bearing in mind that police patrol activity is often dynamic, which is especially the case in urban areas, the diversity of information police officers must possess and the diversity of sources that the information comes from raises the question to what extent police officers can protect the community they serve and respond effectively to the challenges urban environment imposes on them.

Being able to determine which hot spots are known and which hot spots are not known to police officers provides a clearer picture about the accuracy of police perceptions. The fact that (intense) criminal activity is out of the attention of those who are expected to protect citizen safety not only affects police effectiveness but may impact the public's confidence in the police organization as well. Due to this reasoning, this issue should attract the immediate attention of police leadership. The causes of such inaccuracy must be determined, and remedial actions should be taken. These actions may involve some (organizational) changes with regard to data and information collection and/or dissemination. However, it may have wider implications in case inaccuracies of police perceptions are symptoms of some more complex organizational problem (e.g., lack of motivation).

Lack of information about what is happening in the work environment and which actions take place in one's own organization prevents the accomplishment of goals in any activity, including policing. Without accurate and timely data and information, the necessary actions may not be undertaken, or if undertaken, usually this would not be in the place and at the time when they are most needed. For this reason, every opportunity to access such data and information should be utilized. In each police organization, there are established procedures for collecting, analyzing, and disseminating data and information through various channels to police officers. The police organization could have the best information, but if it does not reach the police officers, if it remains unused, then the police organization may miss out on the opportunity to protect someone's life or property. Therefore, it should be periodically evaluated to what extent police officers are familiar with issues of the (patrol) area under their responsibility, and one way is to test the accuracy of a police officer perception of risky areas. This research of police practice in Serbia has shown that the accuracy of these perceptions is not at a satisfactory level and that further work on the improvement of their situational awareness is needed.

No matter how good the analytical system inside the police organization is, what officers 'see' and 'hear' on the street and the informal knowledge they possess, as well as their experience, must not be neglected. Usually, this knowledge is accumulated during the years of service, and it can indicate not only the existence of safety problems that remain undetected through analysis of official police data but also provide important information about the context of their manifestation, possible causes, their temporal dynamics, etc. Research, like the one presented in this paper, represents one possibility to capture this knowledge.

Author Contributions: Conceptualization, Nenad Milic; Methodology, Nenad Milic and Brankica Popovic; Data Curation, Dragan Milidragovic; Visualization, Venezija Ilijazi and Nenad Milic; Writing-Original Draft Preparation, Venezija Ilijazi, Nenad Milic and Brankica Popovic; Writing-Review and Editing and Validation were performed by all authors.

Funding: This research received no external funding.

Acknowledgments: This work was supported by the Ministry of Education, Science and Technological Development of the Republic of Serbia, projects No. 179045 and III 44007. 
Conflicts of Interest: The authors declare no conflict of interest.

\section{References}

1. Gottschalk, P. Police Management: Professional Integrity in Policing; Nova Science Publishers, Inc.: New York, NY, USA, 2010.

2. Ratcliffe, J.H. Intelligence-Led Policing, 2nd ed.; Routledge: London, UK, 2016.

3. Cope, N. Intelligence Led Policing or Policing Led Intelligence? Integrating Volume Crime Analysis into Policing. Br. J. Criminol. 2004, 44, 188-203. [CrossRef]

4. Boba, R. Crime Analysis with Crime Mapping, 2nd ed.; Sage Publications: Thousand Oaks, CA, USA, 2009.

5. Ratcliffe, J.H. Crime mapping and the training needs of law enforcement. Eur. J. Crim. Policy Res. 2004, 10, 65-83. [CrossRef]

6. LeBeuf, M.E.; Paré, S. Police Information Sharing in Canada: Balancing Security, Efficiency and Collaboration; Royal Canadian Mounted Police: Ottawa, ON, Canada, 2005; Available online: http://publications.gc.ca/ collections/Collection/PS64-8-2005E.pdf (accessed on 5 April 2019).

7. Brown, M.M. The Benefits and Costs of Information Technology Innovations: An Empirical Assessment of a Local Government Agency. Public Perform. Manag. Rev. 2001, 24, 351-366. [CrossRef]

8. Moore, M.H. Problem-Solving and Community Policing. Crime Justice 1992, 15, 99-158. [CrossRef]

9. Goldstein, H. Problem-Oriented Policing; McGraw Hill: New York, NY, USA, 1990.

10. Santos, R.B. The effectiveness of crime analysis for crime reduction: Cure or diagnosis? J. Contemp. Crim. Justice 2014, 30, 147-168. [CrossRef]

11. Scott, M.S. Problem-Oriented Policing: Reflections on the First 20 Years; Department of Justice, Office of Community Oriented Policing Services: Washington, DC, USA, 2000.

12. Cordner, G.; Biebel, E. Problem-oriented policing in practice. Criminol. Public Policy 2005, 4, 155-180. [CrossRef]

13. Braga, A.; Weisburd, D. Policing Problem Places: Crime Hot Spots and Effective Prevention; Oxford University Press: New York, NY, USA, 2010; p. 63.

14. Boba, R.; Crank, J. Institutionalizing problem-oriented policing: Rethinking problem solving, analysis, and accountability. Police Pract. Res. 2008, 9, 379-393. [CrossRef]

15. Koper, C.S.; Lum, C.; Willis, J.; Woods, D.; Hibdon, J. Realizing the Potential of Technology in Policing: A Multisite Study of the Social, Organizational, and Behavioral Aspects of Implementing Police Technologies; National Institute of Justice: Washington, DC, USA, December 2015; pp. 34-35. Available online: http: //cebcp.org/wp-content/technology/ImpactTechnologyFinalReport.pdf (accessed on 25 December 2018).

16. Ratcliffe, J.; McCullagh, M. Chasing ghosts? Police perception of high crime areas. Br. J. Criminol. 2001, 41, 330-341. [CrossRef]

17. Doran, B.J.; Burgess, M.B. Putting Fear of Crime on the Map: Investigating Perceptions of Crime Using Geographic Information Systems; Springer: New York, NY, USA, 2012.

18. Pödör, A.; Révész, A.; Rácskai, P.; Sasvár, Z. Measuring citizens fear of crime of using a web application: A case study. GI_Forum 2016, 4, 123-133. [CrossRef]

19. Kohm, S.A. Spatial dimensions of fear in a high-crime community: Fear of crime or fear of disorder? Can. J. Criminol. Crim. Justice 2006, 51, 1-30. [CrossRef]

20. Meško, G.; Fallshore, M.; Muratbegović, E.; Fields, C. Fear of crime in two post-socialist capital cities-Ljubljana, Slovenia and Sarajevo, Bosnia and Herzegovina. J. Crim. Justice 2008, 36, 546-553. [CrossRef]

21. Rengert, G.F.; Pelfrey, W.V. Cognitive mapping of the city center: Comparative perceptions of dangerous places. In Crime Mapping and Crime Prevention; Weisburd, D., McEwen, T., Eds.; Criminal Justice Press: Monsey, NY, USA, 1997; Volume 8, pp. 193-217.

22. Paulsen, J.D.; Robinson, B.M. Spatial Aspects of Crime: Theory and Practice; Pearson Education: New York, NY, USA, 2004.

23. Lopez, N.; Lukinbeal, C. Comparing Police and Residents' Perceptions of Crime in a Phoenix Neighborhood using Mental Maps in GIS. Yearb. Assoc. Pac. Coast Geogr. 2010, 72, 33-55. [CrossRef]

24. Milic, N.; Popovic, B.; Marinkovic, D. Police Officer Perceptions of Crime Hot Spots and the Applicability of Analytical Support of Policing. J. Crim. Investig. Criminol. 2017, 68, 15-30. 
25. Eck, J.; Weisburd, D.L. Crime Places in Crime Theory. In Crime and Place: Crime Prevention Studies; Eck, J., Weisburd, D., Eds.; Criminal Justice Press: Monsey, NY, USA, 1995; Volume 4, pp. 1-33.

26. Sherman, L.W.; Gartin, P.R.; Buerger, M.E. Hot spots of predatory crime: Routine activities and the criminology of place. Criminology 1989, 27, 31-37. [CrossRef]

27. Sherman, L.W.; Weisburd, D. General Deterrent Effects of Police Patrol in Crime "Hot Spots": A Randomized Controlled Trial. Justice Q. 1995, 12, 625-648. [CrossRef]

28. Buerger, M.E.; Cohn, E.G.; Petrosino, A.J. Defining the 'Hot Spots of Crime': Operationalizing Theoretical Concepts for Field Research. In Crime and Place, Crime Prevention Studies; Eck, J., Weisburd, D., Eds.; Criminal Justice Press: Monsey, NY, USA, 1995; Volume 4, pp. 241-248.

29. Farrell, G.; Sousa, W. Repeat victimization and hot spots: The overlap and its implications for crime control and problem-oriented policing. Crime Prev. Stud. 2001, 12, 221-240.

30. Weisburd, D.; Groff, E.; Yang, S.M. The Criminology of Place: Street Segments and Our Understanding of the Crime Problem; Oxford University Press: Oxford, UK, 2012; p. 120.

31. Kappeler, V.E.; Gaines, L.K. Community Policing: A Contemporary Perspective, 7th ed.; Routledge: New York, NY, USA, 2015; p. 87.

32. Lukosch, S.G.; den Hengst-Bruggeling, M.; Horsch, C.H.G.; Datcu, D.; Engelbrecht, H. Exploratory study of a mobile location-based real-time notification system for frontline police officers. J. Univers. Comput. Sci. 2018, 24, 916-934.

33. Luen, T.W.; Al-Hawamdeh, S. Knowledge management in the public sector: Principles and practices in police work. J. Inf. Sci. 2001, 27, 311-318. [CrossRef]

34. O'Shea, T.; Nicholls, K. Police crime analysis: A survey of U.S. police departments with 100 or more sworn personnel. Police Pract. Res. 2003, 4, 233-250. [CrossRef]

35. Taylor, B.; Boba, R.; Egge, J. The Integration of Crime Analysis into Patrol Work: A Guidebook; Office of Community Oriented Policing Services, U.S. Department of Justice: Washington, DC, USA, 2013.

36. Carter, J.G.; Grommon, E. Officer perceptions of the impact of mobile broadband technology on police operations. Polic. Soc. 2017, 27, 847-864. [CrossRef]

37. Sherman, L. Hot Spots of Crime and Criminal Careers of Places. In Crime and Place, Crime Prevention Studies; Eck, J., Weisburd, D., Eds.; Criminal Justice Press: Monsey, NY, USA, 1995; Volume 4, p. 46.

38. Groff, E.R.; Weisburd, D.; Yang, S.M. Is it important to examine crime trends at a local "micro" level? A longitudinal analysis of street to street variability in crime trajectories. J. Quant. Criminol. 2010, 26, 7-32. [CrossRef]

39. Hart, T.C.; Zandbergen, P.A. Kernel density estimation and hotspot mapping: Examining the influence of interpolation method, grid cell size, and bandwidth on crime forecasting. Polic. Int. J. Police Strateg. Manag. 2014, 37, 305-323. [CrossRef]

40. Chainey, S. Examining the influence of cell size and bandwidth size on kernel density estimation crime hotspot maps for predicting spatial patterns of crime. Bull. Geogr. Soc. Liege 2013, 60, 7-19.

41. Milic, N.; Popovic, B.; Mijalkovic, S.; Marinkovic, D. The Influence of Data Classification Methods on Predictive Accuracy of Kernel Density Estimation Hotspot Maps. IAJIT Int. Arab J. Inf. Technol. 2020, 2. accepted for publication. Available online: https:/iajit.org/PDF/March\%202020,\%20No.\%202/13230.pdf (accessed on 5 April 2019).

(C) 2019 by the authors. Licensee MDPI, Basel, Switzerland. This article is an open access article distributed under the terms and conditions of the Creative Commons Attribution (CC BY) license (http://creativecommons.org/licenses/by/4.0/). 